\title{
Emotional Competence, Coping Styles and the Included Student-Teacher Relationship
}

\author{
Cecília Tonial da Silva*,1 \\ Orcid.org/0000-0002-5140-9856
}

Angela Helena Marin ${ }^{1}$

Orcid.org/0000-0002-8056-8661

${ }^{1}$ Universidade do Vale do Rio dos Sinos, São Leopoldo, RS, Brasil

\begin{abstract}
Signed since 1990, school inclusion has brought challenges to the teaching practice not only due to the demands of teaching-learning, but also of the relation with the included student. Therefore, the present study aimed to characterize teachers about emotional competence and coping styles, as well as evaluate the quality of the included student-teacher relationship and the association between these variables. An analytical, quantitative and cross-sectional, observational study was carried out, involving 63 teachers from schools that attend students with deficits in the performance of mental/intellectual functions in São Leopoldo-RS. They responded to the Sociodemographic and Labor Questionnaire, the Inventory of Emotional Competencies, the Brief Scale COPE and the Teacher-Student Relationship Scale. Descriptive and inferential statistical analyzes (Pearson's correlation and Multiple Linear Regression) revealed that although teachers have emotional skills and adaptive coping strategies, the conflict factor was highlighted in the evaluation of the teacher-student relationship, with self-blame, positive reinterpretation and humor being the strategies that best explain it. Thus, the importance of investing in training actions in the area of inclusion is confirmed, since the demands involved in this work tend to overwhelm teachers, reflecting on the quality of their relationship with the included student.
\end{abstract}

Keywords: School inclusion, emotional competence, coping styles, coping, teacher-student relationship.

\section{Competência Emocional, Estilos de Coping e Relação Professor-Aluno Incluído}

\section{Resumo}

Firmada desde 1990, a inclusão escolar trouxe desafios para a prática docente não apenas devido às demandas de ensino-aprendizagem, mas também da relação com aluno incluído. Portanto, o presente estudo teve como objetivo caracterizar os professores quanto a competência emocional e estilos de

* Mailing address: Rua São Joaquim, 611, sala 1202, Centro, São Leopoldo, RS, Brasil 93010-190. E-mail: ceciliatonial@hotmail.com and marin.angelah@gmail.com

Article derived from the Master's thesis of Cecília Tonial da Silva, conducted under the guidance of Angela Helena Marin, presented to the Graduate Program in Psychology of Vale do Rio dos Sinos University - São Leopoldo - RS, Brasil. 
coping, bem como avaliar a qualidade da relação professor-aluno incluído e a associação entre essas variáveis. Realizou-se um estudo com delineamento observacional analítico, de abordagem quantitativa e corte transversal, do qual participaram 63 professores de escolas que atendem alunos com déficits no desempenho de funções mentais/intelectuais no município de São Leopoldo-RS. Eles responderam ao Questionário Sociodemográfico e Laboral, Inventário de Competências Emocionais, Escala Brief COPE e Escala de Relacionamento Professor-Aluno. Análises estatísticas descritivas e inferenciais (correlação de Pearson e Regressão Linear Múltipla) revelaram que embora os professores apresentem competências emocionas e estratégias de coping adaptativas, o fator conflito se destacou na avaliação da relação professor-aluno, sendo a autoculpabilização, reinterpretação positiva e humor as estratégias que melhor o explicam. Confirma-se, assim, a importância de investir em ações de formação na área da inclusão, pois as demandas envolvidas neste trabalho costumam sobrecarregar os professores, refletindo sobre a qualidade de sua relação com o aluno incluído.

Palavras-chave: Inclusão escolar, competência emocional, estilos de enfrentamento, relação professoraluno.

\section{Competência Emocional, Estilos de Coping y Relación Profesor-Alumno Incluido}

\section{Resumen}

Desde 1990, la inclusión escolar ha traído desafíos para la práctica docente debido a las demandas de enseñanza-aprendizaje y relación con el alumno incluido. El objetivo de este estudio fue caracterizar a los profesores en términos de competencia emocional y estilos de enfrentamiento, así como evaluar la calidad de la relación profesor-alumno incluida y la asociación entre esas variables. Con el diseño analítico-observacional, abordaje cuantitativo y transversal, participaron del estudio 63 profesores de escuelas que atienden a alumnos con déficit en el desempeño de funciones mentales / intelectuales en el municipio de São Leopoldo-RS. En el caso de las mujeres, se observó un aumento de la mortalidad infantil. El análisis estadístico descriptivo e inferencial (correlación de Pearson y Regresión Lineal Múltiple) reveló que, aunque los profesores tenían habilidades y estrategias de enfrentamiento adaptativo emocionantes, factor de conflicto destacado en la evaluación de la relación profesor-alumno, siendo la auto-culpa, reinterpretación positivo y humor las estrategias que mejor explican. Esto confirma la importancia de invertir en acciones de formación en el área de la inclusión, ya que las demandas involucradas en este trabajo tienden a sobrecargar a los profesores, reflejando en la calidad de su relación con el alumno incluido.

Palabras clave: Inclusión escolar, competencia emocional, estilos de enfrentamiento, relación profesoralumno.

School inclusion is a much discussed topic due to the high incidence of enrollment of students with some kind of disability, especially in public schools of regular education. This demand stems from guidelines such as the Convention on the Rights of the Child, which came into force through Decree No. 99710 (1990), the World Declaration on Education for All and the Salamanca Statement (United Nation Educational, Scientific and Cultural Organization [UNESCO], 1994), which established that children, adolescents and adults with special educational needs had the same rights as everyone else regarding access to education. Since then, new regulations have been developed aiming to fulfill this demand. For example, the National Policy on Special Education from the Perspective of Inclusive Education (Politica Nacional de Educação Especial na Perspectiva da Educação Inclusiva; Portaria $\mathrm{n}^{\circ} 948,2008$ ) instituted specialized educational services for students with disabilities, developmental 
disorders and high skills/giftedness, in all the levels of education, as well as highlighting the importance of providing training for teachers and developing specific didactic material. Goal 4 of the National Plan of Education (Plano Nacional de Educação - PNE), also stipulated that these students, aged between 4 and 17 years, have access to Fundamental Education and specialized educational service (SES), mainly in the regular education network (Law No. 13005, 2014).

According to data from the last School Census (2017), approximately $87 \%$ of students with disabilities, developmental disorders and high skills were enrolled in regular classes in elementary education and $98.9 \%$ in high school education (Ministério da Educação, 2018). However, only $40 \%$ of the students included had access to the SES (Ministério da Educação, 2018), as it was not provided by many schools.

The students included in the present study were those with deficits in the performance of structural (mental and intellectual) functions, not considering students with physical disabilities or with high skills. Students with intellectual disabilities have few skills to adapt to everyday situations, whether related to routine, self-care or interpersonal conditions (Araújo \& Silva, 2017). Therefore, this type of disability has been highlighted as one of the most challenging in the context of inclusion, since it counterposes one of the primary functions of schools, which is the construction of knowledge.

In order to promote the inclusion of students with deficits in structural functions, it is important to consider the specific learning needs of each one. This would imply considering the characteristics and interests of these students in the development of tools and resources to promote their development (Brandão \& Ferreira, 2013; Magalhães \& Soares, 2016; Santos \& Batista, 2015), making the curriculum more flexible (Cruz \& Glat, 2014). However, it can be observed that schools often fail to adapt their educational actions due to limitations related to the curriculum and the physical structure (RosinPinola \& Del Prette, 2014; Santos \& Martins, 2015). Poker, Valetim, and Garla (2017) highlighted that, even though students with disabilities have access to regular education, there are still many gaps to be filled regarding the quality of the learning, which may be related to how the relationship between teacher and student is established.

Teachers involved in the inclusion process, faced with the difficulties presented, tend to experience stressful situations (Platsidou, 2010), which affect their motivation and optimism (Carlotto, Librelotto, Pizzinato, \& Barcinski, 2012). These feelings may interfere with the teacher's performance in the classroom, as observed in the study by Sekkel, Zanelatto, and Brandão (2010), who verified few actions of socialization and learning in the practice of early childhood education teachers with included students. Similarly, Fantacini and Dias (2015) indicated that the SES teachers demonstrated difficulties and resistance to modify teaching strategies directed toward students with intellectual disabilities.

Accordingly, an interrelationship can be observed between the psychological aspects of teachers and their professional performance, as one of the main limitations found is the establishment of the relationship with the included students, not only accepting them, but promoting the interaction with them. The collaborative attitude of teachers seems to guarantee more effective inclusion (Brandão \& Ferreira, 2013), because it is through their observations that students with deficits in the performance of structural functions can learn new ways of interacting (Costa, 2008).

The collaborative attitude of the teacher is associated with emotional competence, which can be understood as the ability to identify emotions in oneself and in others, to understand their functioning and how they affect one's behavior and that of others, to think when emotionally activated and to regulate one's emotional states (Mayer \& Salovey, 1997). These characteristics allow the teacher to better solve the stressful situations experienced in the school (Vargas, 2015). In addition, it is believed that emotional competence is related to coping styles (Carver, Weintraub, \& Scheier, 1989), understood as 
cognitive and behavioral strategies (Folkman \& Lazarus, 1980) that lead to stress responses, affecting the ways of acting in future situations (Carver \& Scheier, 1994).

It is known that practicing the teaching profession requires skills to deal with the difficulties inherent to the inclusion context, which is usually permeated by problems of student behavior, such as low motivation to learn and perform tasks, indiscipline (Cruz, Gomes, \& Melo, 1997) and relational distancing from their family members (Fernandes, Maciel, \& Carlotto, 2016), who are sometimes in a situation of social vulnerability. Therefore, the assertive and affective attitudes of the teacher (Santos, 2016), as well as the use of adaptive coping strategies become important, as they tend to result in a favorable classroom climate, enabling a higher quality relationship with the students, in addition to enabling new ways of teaching (McDonald et al., 2016).

It is believed, therefore, that cooperation and the construction of bonds with the included students, will facilitate their adaptation to the school and the accomplishment of the proposed activities, as well as making them more autonomous and active (Malaquias \& Sekkel, 2014; Santos, 2016). However, it is necessary for the teacher to have the knowledge and theoretical basis to construct and evaluate adequate strategies to explore their development (Portilho, Batista, Banas, \& Oliveira, 2017), which should be a focus of training in the area (Poker et al., 2017).

In view of the above, the present study aimed to characterize teachers of students with deficits in the performance of structural functions regarding their emotional competence and coping styles, as well as to evaluate the quality of the teacher-student relationship and to examine the extent to which emotional and coping styles explain the quality of this relationship. As the hypothesis, it was proposed to investigate whether the presentation of emotional competences and adaptive coping styles favors the quality of the relationship between teacher and included student. Given the scarcity of localized studies that relate these concepts, especially in the context of inclusion, it is necessary to carry out research that theoretically and methodologically supports the construction of an adequate environment for the development of skills, especially emotional competence, due to its importance in the learning processes, and adaptive coping styles, which can promote consistent educational practices. The need for this to be individualized and planned with a view to the specificities of each student, as indicated by the legislation (Decree No. 7611, 2011) should also be considered.

\section{Method}

\section{Design and Participants}

This was an observational-analytical study (Grimes \& Shulz, 2002), with a cross-sectional quantitative approach, in which 63 teachers from public schools in São Leopoldo-RS, selected by convenience, participated. The majority were women $(98.4 \%)$, with a mean age of 43.1 years $(S D=8.30)$, married or in a stable union $(54.0 \%)$ and with a mean of 1.6 children $(S D=0.91)$.

All taught students evaluated by the Center of Support and Research for the Inclusion Process (Núcleo de Apoio e Pesquisa ao Processo de Inclusão - NAPPI) as having deficits in the performance of structural (mental/intellectual) functions. They had 19.59 years of teaching experience $(S D=8.96), 8.46$ years with inclusion students $(S D=6.71)$, attending about 8 students each $(S D=6.71)$. A total of $14.3 \%$ worked in the SES and the others in the classroom. Their mean weekly workload was 38.6 hours $(S D=$ 14.09). Table 1 shows more data on the training of the teachers, as well as their evaluation of the quality of the physical structure and the materials provided for inclusion students.

\section{Instruments}

The instruments were chosen considering the objectives of the study and the fact that they were developed or already adapted for the Brazilian population. A Sociodemographic and Work Data Questionnaire (adapted from Moreira \& Sigolo, 2009) was designed to obtain data regarding schooling, marital status, age, training, 
Table 1

Training of the Teachers and Evaluation of the Physical Structure and Materials Provided for School Inclusion

\begin{tabular}{|c|c|}
\hline Training & $\%$ \\
\hline Training in pedagogy & 42.9 \\
\hline Undergraduate degree in the area & 41.3 \\
\hline Training in teaching & 1.6 \\
\hline Specialization & 68.3 \\
\hline MSc. & 4.8 \\
\hline $\mathrm{PhD}$. & 1.6 \\
\hline Participated in pedagogical meetings regarding inclusion & 76.2 \\
\hline Did not take courses or training regarding inclusion & 54.4 \\
\hline \multicolumn{2}{|l|}{ Quality evaluation } \\
\hline \multicolumn{2}{|l|}{ Physical structure of the school for inclusion } \\
\hline Good & 77.9 \\
\hline Very good & 20.6 \\
\hline \multicolumn{2}{|l|}{ Materials provided for inclusion students } \\
\hline Good & 44.4 \\
\hline Reasonable & 28.6 \\
\hline Poor & 12.7 \\
\hline Very good & 12.7 \\
\hline
\end{tabular}

teaching work, work in inclusive education and health. In addition, the Emotional Competence Inventory (Inventário de Competências Emocionais - ICE-R), developed and validated by Bueno, Correia, Abacar, Gomes, and PereiraJúnior (2015) was used to evaluate skills related to emotional intelligence such as recognition of emotions, emotion as a facilitator of thinking, comprehension and management of emotions. It consists of 34 items, answered on a five-point Likert-type scale $(1=$ does not apply in my case, $5=$ applies perfectly in my case). Among these, eight items refer to factor 1, perception of emotions (ability to recognize emotions); seven items to factor 2, regulation of low-power emotions (ability to regulate a negative emotional state, such as sadness, guilt, discouragement); four items to factor 3, emotional expressiveness (ability to communicate and express emotions); seven items to factor 4 , regulation of emotions in other people (ability to confront emotionally altered people, helping them to seek emotional regulation); and eight items to factor 5, regulation of high-power emotions (ability to regulate emotions such as anxiety, excitement, anger). It should be emphasized that the data can also generate a general factor of emotional competence, obtained through the addition of factors 1, 2 and 4, however, this was not used because it was indicated by the authors as a second-order factor. In the present study, the Cronbach's alpha obtained for the general factor was 0.88 . The indices were: factor 1 $\alpha=0.80$, factor $2 \alpha=0.65$, factor $3 \alpha=0.28$ and factor $4 \alpha=0.89$. For factor 3 , reliability was calculated using the Split-Half method, obtaining a correlation value of 0.53 between the two halves, which indicates an acceptable level of reliability. This method is used to evaluate the internal consistency of samples that are 
not representative of the number of items to be submitted to the reliability analysis (Osbourn, 2000).

The Brief COPE Scale, a reduced version of the COPE (Carver et al., 1989) was also applied, which was adapted to Brazilian Portuguese and had its psychometric properties evaluated by Brasileiro (2012). The instrument examines coping styles, through 28 items evaluated using a four-point Likert-type scale $(1=\mathrm{I}$ never do this and $4=$ I always do this), and consists of 14 dimensions, grouped into two scales: 1) adaptive strategies $(\alpha=0.72)$, which includes active coping (acting to minimize or extinguish the stressor event), planning (reasoning about how to deal with the problem), use of emotional support (seeking emotional support from another person), use of instrumental support (obtaining information or help), positive reinterpretation (seeing or extracting something positive from the situation), acceptance (accepting the reality of the facts), religiosity (seeking religion to deal with the problem) and humor (making jokes about the problem); and (2) maladaptive strategies $(\alpha=0.60)$, which include expression of feelings (high self-awareness about stress experienced, tendency to externalize or repress emotions), denial (efforts to deny the reality of the stressor), substance use (use drugs or alcohol to deal with the problem), body disinvestment (decrease in the effort to reach the goal to which the stressor event is connected), self-distraction (mental disinvestment or avoidance behaviors) and self-blame (criticizing or blame oneself for the problem). For the present sample, the majority of the dimensions obtained acceptable levels of reliability [active coping $\alpha=0.54$; planning $\alpha=0.62$; instrumental support $\alpha=$ 0.77 ; emotional support $\alpha=0.85$; religiosity $\alpha=$ 0.88 ; self-blame $\alpha=0.61$; acceptance $\alpha=0.77$; self-distraction $\alpha=0.68$; body disinvestment $\alpha=$ 0.65 ; use of substances $\alpha=0.70$; and humor $\alpha=$ 0.56], however, for the factors with Cronbach's alphas estimated as low, the Split-Half method was considered and the correlations showed internal consistencies of 0.50 for positive reinterpretation; of 0.60 for the expression of feelings factor and 0.57 in the negation factor.
Finally, the Teacher-Student Relationship Scale (Escala de Relacionamento ProfessorAluno - ERPA; Petrucci, Borsa, Barbosa, \& Koller, 2014) was used, in its abbreviated version and adapted from the STRS-SF (Pianta, 1992), which evaluates, from the perspective of the teachers, aspects regarding the quality of the relationship with the student. The questionnaire consists of 15 items, the answers to which are evaluated using a five-point Likert-type scale $(1=$ certainly does not apply and $5=$ definitely applies). Seven of the items correspond to the affinity dimension (positive perception of the interaction, characterized by stability, affection and accessibility) and the other eight to the conflict dimension (teacher's perception of negative aspects, such as disagreements and instability in the interaction with the student). For the sample of this study the reliability indices for the affinity $(\alpha=0.81)$ and conflict $(\alpha=0.77)$ dimensions were classified as high.

\section{Ethical Procedures and Data Collection}

After approval from the Research Ethics Committee of the University of Vale do Rio dos Sinos (CAEE: 65197817.6.0000.5344) and from the Department of Education and the NAPPI of the municipality of São Leopoldo-RS, the data were collected. All pertinent documents, such as the Letter of Consent of the school board and the Consent Form addressed to the teachers, were duly signed. The instruments were applied on the premises of the schools on a pre-arranged day and time and were administered individually and at random, with duration of 20 to 30 minutes. The researchers were available to answer any questions from the participants.

\section{Data Analysis Procedures}

The responses of the Sociodemographic and Work Data Questionnaire were analyzed through descriptive statistics to characterize the sample. The absolute $(n)$ and relative (\%) distributions were used, as were the measures of central tendency and dispersion (mean and standard deviation), with the study of the normality of the distribution of the data made through the 
Kolmogorov-Smirnov test (Lillifors correction), which indicated a normal distribution sample $(p$ $>$.06). The data regarding emotional competence, coping styles and the teacher-student relationship were tabulated according to their authors' indication and analyzed descriptively.

In order to verify the existence of linearity relationships between the variables investigated, Pearson's correlation analysis was performed and to identify which factors of the emotional competence and coping scales explained the dimensions of the teacher-student relationship the Multiple Linear Regression Analysis (backward stepwise method) technique was used. The assumptions of normality and homogeneity of errors and their independence were verified (Durbin-Watson statistic; Field, 2009; Marôco, 2011). The Variance Inflation Factor (VIF) values were used for the multicollinearity diagnosis. The variables that would compose the initial model were determined according to the results presented by the correlation analysis, considering those that obtained significance level of $20 \%$ or less (Hair, Babin, Anderson, $\&$ Tatham, 2009). The percentage of variance explained by the model was estimated using the adjusted coefficient of determination (adjusted $R^{2}$ ). The data were analyzed using the Statistical Package for the Social Sciences version 20.0 program for Windows, adopting a 5\% level of significance for statistical decision criteria.

\section{Results}

In order to fulfill the objective of characterizing the teachers of included students, descriptive analyses were performed regarding their emotional competence and coping styles, as well as their evaluation of the quality of the relationship between the teachers and students with performance deficits in the structural functions. Regarding emotional competence, the perception of emotions $(M=4.09 ; S D=$ $0.63)$, emotional expressiveness $(M=3.77 ; S D=$ $0.59)$, the regulation of low-power emotions ( $M$ $=3.64 ; S D=0.55)$, the regulation of emotions in other people $(M=3.62 ; S D=0.74)$ and the regulation of high-power emotions $(M=3.61$;
$S D=0.62$ ) were highlighted. Regarding coping styles, the highest means were observed in the active coping $(M=3.38 ; S D=0.73)$, planning $(M=3.40 ; S D=0.65)$, positive reinterpretation $(M=3.08 ; S D=0.72)$, acceptance $(M=3.04$; $S D=0.85)$ and adaptive strategies $(M=3.24$; $S D=0.58)$ dimensions. The lowest means were identified in the negation $(M=1.63 ; S D=0.69)$, body disinvestment $(M=1.43 ; S D=0.68)$, substance use $(M=1.34 ; S D=0.71)$ and humor $(M=1.71 ; S D=0.83)$ dimensions. In relation to the teacher-student relationship, the highest mean was in the conflict factor $(M=4.09 ; S D$ $=0.69)$, followed by the general conflict and affinity factor $(M=3.24 ; S D=0.48)$ and the affinity factor $(M=2.36 ; S D=0.44)$.

Next, to verify the association between these variables, adding the sociodemographic and work data, Pearson's correlation analysis was performed. Weak significant relationships were found between the sociodemographic and work data and the emotional competence factors, coping scales and dimensions of the teacherstudent relationship. Similarly, the majority of the correlations between the emotional competence factors and coping scales were also classified as weak, with some being moderate. For the quality of the teacher-student relationship, the majority of the associations found were also weak. The data are presented in Table 2 .

In order to examine to what extent emotional competence and coping styles explained the quality of the relationship between the teacher and included student, Multiple Linear Regression Analysis (backward stepwise method) was used. The initial response model for the variations of the affinity dimension was composed by the coping scales: self-blame $(r=-0.29 ; p<.02)$; body disinvestment $(r=-0.26 ; p=.05)$ and total maladaptive strategies $(r=-0.23 ; p<.08)$. Regarding emotional competence, the following factors were considered: perception of emotions in other people $(r=0.19 ; p<.14)$; regulation of low-power emotions $(r=0.19 ; p<.14)$; emotional expressiveness $(r=0.29 ; p<.03)$; regulation of emotion in other people $(r=0.45 ; p<.01)$; and regulation of high-power emotions $(r=0.49 ; p$ $<.01)$. According to the results obtained, the final 
Table 2

Correlations between Sociodemographic and Work Data, Emotional Competence, Coping Styles and Teacher-Student Relationships

\begin{tabular}{|c|c|c|c|}
\hline \multirow[t]{2}{*}{ Factors } & & \multicolumn{2}{|c|}{ Pearson's correlations } \\
\hline & & $r$ & $p$ \\
\hline \multirow[t]{3}{*}{ Age of the teacher } & Length of inclusion experience & -0.27 & .04 \\
\hline & Acceptance & -0.25 & .04 \\
\hline & Body disinvestment & 0.38 & .001 \\
\hline \multirow[t]{2}{*}{ Time since training } & Self-blame & -0.38 & .001 \\
\hline & Maladaptive strategies & 0.28 & .04 \\
\hline Length of time teaching & Affinity & -0.32 & .001 \\
\hline \multirow[t]{6}{*}{ Number of students attended } & Weekly workload & 0.26 & .03 \\
\hline & Active coping & -0.34 & .001 \\
\hline & Planning & -0.33 & .001 \\
\hline & Instrumental Support & -0.27 & .03 \\
\hline & Emotional support & -0.25 & .04 \\
\hline & Humor & 0.28 & .02 \\
\hline Self-blame & Regulation of Emotions in Other People & -0.39 & .01 \\
\hline \multirow[t]{2}{*}{ Negation } & Perception of Emotions & 0.32 & .01 \\
\hline & Regulation of Emotions in Other People & 0.35 & .01 \\
\hline Self-distraction & Regulation of High-Power Emotions & 0.28 & .02 \\
\hline \multirow[t]{3}{*}{ Body disinvestment } & Perception of Emotions & -0.30 & .01 \\
\hline & Regulation of Low-Power Emotions & -0.26 & .04 \\
\hline & Regulation of Emotions in Other People & -0.33 & .01 \\
\hline \multirow[t]{3}{*}{ Substance use } & Perception of Emotions & -0.38 & .01 \\
\hline & Regulation of Emotions in Other People & -0.33 & .01 \\
\hline & Regulation of High-Power Emotions & -0.43 & .001 \\
\hline \multirow[t]{3}{*}{ Maladaptive strategies } & Perception of Emotions & --0.41 & .01 \\
\hline & Regulation of Low-Power Emotions & -0.30 & .01 \\
\hline & Regulation of Emotions in Other People & -0.32 & .01 \\
\hline \multirow[t]{5}{*}{ Affinity } & Self-blame & -0.29 & .02 \\
\hline & Body disinvestment & -0.25 & .04 \\
\hline & Emotional Expression & 0.28 & .02 \\
\hline & Regulation of Emotions in Other People & 0.44 & .001 \\
\hline & Regulation of High-Power Emotions & 0.41 & .001 \\
\hline \multirow[t]{4}{*}{ Conflict } & Body disinvestment & 0.26 & .04 \\
\hline & Humor & 0.34 & .001 \\
\hline & Maladaptive strategies & 0.31 & .01 \\
\hline & Regulation of Low-Power Emotions & 0.27 & .03 \\
\hline
\end{tabular}


response model for the affinity dimension was listed in seven steps $\left(F_{2 ; 54}=8.808 ; p<.01 ; R_{\text {model }}^{2}\right.$ $=0.25)$ and showed significance for self-blame $\left(b_{p}=0.25 ; p=.04 ; R_{p}^{2}=0.08\right)$ and regulation of high-power emotions $\left(b_{p}=0.38 ; p<.002 ; R_{p}^{2}\right.$ $=0.16)$. Regarding these variables, the model was able to explain $24.6 \%\left(R_{\text {model }}^{2}=0.25\right)$ of the variations observed in the affinity dimension.

In the determination of the regression response model for the variation in the conflict dimension, the coping scales related to religiosity $(r=0.20 ; p<.12)$, reinterpretation $(r$ $=0.20 ; p<.11)$, acceptance $(r=0.22 ; p<.09)$, self-blame $(r=0.17 ; p<.19)$, expression of feelings $(r=0.20 ; p<.11)$, humor $(r=0.35 ; p$ $<.01)$ and total maladaptive strategies $(r=0.31$; $p<.02)$ were listed for the initial model. In relation to emotional competence, the perception of emotions in other people $(r=-0.24 ; p<.06)$ and regulation of low-power emotions ( $p=$ $-.27 ; p<.03)$ factors participated in the model. Considering the estimation obtained for the final model, selected in five steps $\left(F_{3 ; 57}=5.71 ; p<.002\right.$; $R_{\text {model }}^{2}=0.23$ ), the results indicated that $23.1 \%$ of the variance observed in the conflict dimension could be explained by humor $\left(b_{p}=0.33 ; p=\right.$ $.006 ; R_{p}^{2}=0.12$ ), followed by reinterpretation $\left(b_{p}=0.20 ; p=.09 ; R_{p}^{2}=0.05\right)$, and regulation of low-power emotions $\left(b_{p}=-0.27 ; p=.02\right.$; $R_{p}^{2}=0.09$ ). It should be mentioned that the variables listed in the final models that were not significant remained in the model because they exert an influence on the other independent variables. This influence is characterized by potentiating the explanatory power of one or more independent variables.

\section{Discussion}

Considering that the teacher is a mediator of the interactions in the school environment, being important to enable the inclusion of students with deficits in structural functions in the classroom, it was verified that the participants of this study contradicted data documented in the literature that indicate the individual and isolated practice. This would lead to greater difficulty in solving problems and developing inclusive actions
(Vilaronga \& Mendes, 2014). The perception of support by the pedagogical team of the school and external professionals, such as those that make up the NAPPI, was identified. They also positively evaluated the school structure and the pedagogical materials that were available for the included students, an aspect that is indicated in several studies as precarious, making it difficult to carry out activities adequately (Carneiro \& Uehara, 2016; Pinto, Lima, \& Silva, 2005). The positive evaluation of the support received and the structure and materials may have influenced the teachers to adopt more adaptive strategies such as active coping, emotional control, planning, reinterpretation and acceptance, suggesting that they perceive themselves as having a greater sense of control to cope with difficult situations, seeking to solve them in an active way, in order to minimize the stress experienced.

Another fact that highlights the mental health of the teachers investigated was the negative association between the factors of perception of emotions, regulation of low-power emotions and regulation of high-power emotions with the substance use style of coping, as well as the regulation of emotions factor which correlated positively with the self-distraction coping style, indicating that the participants sought to adjust and choose to continue or not to invest in difficult situations that could provoke anger or euphoria, for example.

Despite the positive evidence, it was also found that when coping with practical issues such as dealing with the included student, especially when there are several, the coping strategies most used were active coping, planning, instrumental support, emotional support and humor. These suggest less effort and reflection in seeking to solve the problem, as well as greater solicitation of social and emotional support, since they refer to not valuing the preparation of activities and management of the class. This usually indicates a reduction of the motivational level of the teacher for the practice regarding inclusion (Tsai, Fung, \& Chow, 2006).

It was also observed that the older teachers used coping strategies such as body disinvestment and acceptance, indicating a tendency 
towards styles more focused on emotions rather than problem solving, showing a more negative attitude and, consequently, a higher level of conflict in the relationship with the student. These data converge with those found by Vaz et al. (2015), who reported that older teachers demonstrated negative attitudes toward their included students, possibly due to more traditional and dated concepts regarding the learning model.

According to these results, longer time since undergoing training was associated with the use of self-empowerment and total maladaptive strategies and more teaching experience with lower affinity in the teacher-student relationship. Although Fakolade, Adeniyi, and Tella (2009) found no relationship between time since training and attitudes of the teachers, Hwang and Evans (2011) indicated that teachers with longer times since training showed more negative attitudes towards inclusion. Barbosa Campos, and Valentim (2011) highlighted that teachers with more experience in the teaching profession presented greater conflict and less affinity in relation to the included students because they were more concerned with correcting them than considering them in their specificities.

It was observed that maladaptive strategies, as well as the style of coping, were associated with the perception of emotions, regulation of low-power emotions and regulation of highpower emotions, which indicates that teachers tend to use more styles of confrontation aimed at not accepting the facts and have less positive attitudes, avoiding expressing or repressing feelings. It is possible that this attitude is contributing to feelings of frustration with the problems experienced, as highlighted by Eisenhower, Baker, and Blacher (2007), reflecting how teachers still do not feel able to deal with the included student. Thus, the perception of low self-efficacy in the relationship with the included student, already indicated in other studies (Vaz et al., 2015), can be corroborated, which may affect the choice of strategies used to solve problems.

The negative association of the denial coping style with the perception of emotions and the regulation of the emotions of other people factors suggests that the teachers have an avoidant attitude, presenting difficulty in identifying and regulating emotions, especially in situations in which they need to deal with behaviors of agitation and instability of its students in order to adjust the relationship, which seems to be consistent in situations of inclusion (Mendonça, 2017). Accordingly, Skaalvik and Skaalvik (2015) verified that teachers recognized themselves as flawed and incapable of adapting tasks for dealing with students with special educational needs. One of the reasons was the short time they had available, with them choosing to work longer hours trying to cope even if they did not have emotional conditions, avoiding days off so they did not feel guilty. However, for Forlin (2001) the teachers' belief in their low ability to teach included students indicates a work overload.

In contrast to the data, it is possible to understand the presence of higher levels of conflict in the teacher-student relationship (Capelo \& Pocinho, 2016; Pinto et al., 2005). This dimension was positively associated with maladaptive coping styles, such as body disinvestment and humor, indicating that the participants invested less effort and used humor more to deal with stressful situations related to inclusion. Similarly, conflict was negatively correlated with the regulation of low-power emotions, which indicates an attempt to suppress unpleasant emotions. This may be associated with escape behaviors and less interest and commitment to cooperate and interact with the included student (Bueno et al., 2015).

Specifically considering students with intellectual disabilities, Fernandes, Andrade and Ferreira (2017) found behavior of accommodation by the teacher, due to indicators of low attention and emotional concentration of the students, as well as hyperactivity, which may reflect the fragility of the teaching management (Picado \& Rose, 2009). In addition, in the study of Eisenhower et al., (2007) the inability for self-regulation and the behavior of greater dependence of the student with intellectual disabilities were considered factors for less 
proximity of the teacher. Therefore, teachers may perceive themselves as less able and more unprepared to deal with situations involving students with intellectual disabilities (Greguol, Malagodi, \& Carrato, 2018), which also tends to affect the behavioral reactions of the students, since this can be perceived as not accepting them (Macedo \& Medina, 2017).

However, when there is affinity, which in this study had less expression in the evaluation of the included student-teacher quality, the construction of assertive attitudes is favored (Fachinetti, Nascimento, \& Giroto, 2016) and feelings of frustration related to lack of or slow learning tend to decrease. Studies emphasize the importance of investing in the bond so that included students learn social skills and appropriate behaviors, which contribute to the quality of this relationship (Fantacini \& Dias, 2015; Katz \& Mirenda, 2002; Mello \& Rubio, 2013).

Finally, in relation to the factors or dimensions evaluated that revealed the quality of the teacher-student relationship, it was verified that the lower use of the self-blame coping style and the greater regulation of high-power emotions managed to explain the higher levels of affinity, since both are contingencies for the expression of behavior, allowing self-motivation to be maintained (Veiga-Branco, 2004). The conflict was better explained by humor coping styles and positive reinterpretation, as well as by less use of the regulation of low-power emotions. It is plausible to assume that, in general, teachers who do not perceive learning potential in their students with deficits in the performance of structural functions possibly discouraging them from cooperating in the classroom (Silva, 2015), which favors conflict.

In general, the data indicate that even when presenting good emotional competence and the use of more adaptive coping styles, the relationship between the teacher and the included student stands out as conflicting, which leads to the belief that difficulties remain in the handling of situations experienced in the classroom with these students. Therefore, even if teachers have the resources to deal with the demands of these students, they do not seem to put them into practice in the relationship, often limiting themselves to routine and repetitive activities that become exhausting for both.

\section{Final Considerations}

It is known that the requirements implied for the inclusion of students, especially those with deficits in the performance of structural functions, is seen as a constant challenge that can provoke resistance and restlessness in the teachers (Ferreira, Prado, \& Cadaveico, 2015). Therefore, attention to teacher training for action in the area becomes imperative. However, as Veiga-Branco (2004) states, this needs a response to the paradigm shift that understands the students as interactional subjects, considering their social and emotional development as important for achieving their academic goals.

Thus, the teachers, as important actors in the inclusion process, will need a certain level of emotional competence to manage conflicts, to acknowledge their feelings and those of others and to help them regulate them. This would make it possible to consolidate the bond, which is fundamental for the relationship with the included student (Campos \& Martins, 2012). In this sense, the data of the present study confirmed that emotional competence factors, such as the ability to regulate impulses and feelings, as well as some coping styles, such as not criticizing oneself for what happens in stressful situations, are fundamental for affinity in the included student-teacher relationship. However, the inability to deal with emotions related to frustration, discouragement, the failure to see the situation more favorably or make the best of it and making jokes about the stressor lead to conflict.

The results present some limitations such as the fact that they refer to a specific sample from a municipality of a metropolitan region of the state of Rio Grande do Sul and the fact that other emotional aspects were not considered such as the presence of symptoms that refer to psychopathologies. However, the results were shown to be coherent and interesting in that they 
can help in the elaboration and implementation of proposals aimed at improving the quality of the teacher-student relationships in the context of inclusion. Furthermore, it became clear how fragile the school system is in relation to the inclusion process. This, therefore, corroborates the indications of Poker et al. (2017) regarding the presence of many gaps in relation to the quality of learning of included students. Even though these students now have more access to regular education, many investments are still necessary to make the inclusion effective.

It is hoped that the discussion will help health and education professionals to develop skills directed toward the qualification of their practices. It is also of great importance to invest in research that addresses variables related to the emotional and behavioral issues of teachers, since these seem to affect their relationship with the student, being reflected in the quality of the education that is advocated for all.

\section{References}

Araújo, N. S. R., \& Silva, E. R. A. (2017). A inclusão do aluno com deficiência intelectual na escola regular. Revista Cientifica FATECIE, 2(2), 95113.

Barbosa, A. J. G., Campos, R. A., \& Valentim, T. A. (2011). A diversidade em sala de aula e a relação professor-aluno. Estudos de Psicologia (Campinas), 28(4), 453-461. http://dx.doi. org/10.1590/S0103-166X2011000400006

Brandão, M. T., \& Ferreira, M. (2013). Inclusão de crianças com necessidades educativas especiais na educação infantil. Revista Brasileira de Educação Especial, 19(4), 487-502.

Brasileiro, S. V. (2012). Adaptação transcultural e propriedades psicométricas do COPE breve em uma amostra brasileira (Master's thesis, Universidade Federal de Goiás, Goiânia, GO, Brazil). Retrieved from https://repositorio. bc.ufg.br/tede/handle/tede/3351

Bueno, J. M. H., Correia, F. M. D. L., Abacar, M., Gomes, Y. D. A., \& Pereira-Júnior, F. S. (2015). Competências emocionais: Estudo de validação de um instrumento de medida. Avaliação Psicológica, 14(1), 153-163.
Campos, S., \& Martins, R. (2012). A inteligência emocional em professores de educação especial da região de viseu. Millenium, 43, 7-28.

Capelo, R., \& Pocinho, M. (2016). Estratégias de coping: Contributos para a diminuição do estresse docente. Psicologia, Saúde e Doenças, 17(2), 282-294. doi: 10.15309/16psd170213

Carlotto, M. S., Librelotto, R., Pizzinato, A., \& Barcinski, M. (2012). Prevalência e factores associados à Síndrome de Burnout nos professores de ensino especial. Análise Psicológica, 30(3), 315-327.

Carneiro, R. U. C., \& Uehara, F. (2016). A inclusão de alunos público-alvo da educação especial no ensino fundamental I através do olhar dos professores. Revista Ibero-Americana de Estudos em Educação, 11(2), 911-934. doi: 10.21723/riaee.v11.esp2.p911-934

Carver, C. S., \& Scheier, M. F. (1994). Situational coping and coping dispositions in a stressful transaction. Journal of Personality and Social Psychology, 66(1), 184-195.

Carver, C. S., Weintraub, J. K., \& Scheier, M. F. (1989). Assessing coping strategies: A theoretically based approach. Journal of Personality and Social Psychology, 56(2), 267238. doi: 10.1037/0022-3514.56.2.267

Costa, A. E. B. (2008). Modelação. In A. Bandura, R. G. Azzi, \& S. Polydoro (Eds.), Teoria social cognitiva: Conceitos básicos (pp. 123-148). Porto Alegre, RS: Artmed.

Cruz, G. C., \& Glat, R. (2014). Educação inclusiva: Desafio, descuido e responsabilidade de cursos de licenciatura. Educar em Revista, 52, 257-273.

Cruz, J. F., Gomes, A. R., \& Melo, B. T. (1997). Stress ocupacional em profissionais de saúde e do ensino. Psicologia: Teoria, Investigação e Prática, 2(1), 53-72.

Decree No. 7611. (2011, November 17). Brasília, DF: Ministro da Educação.

Decree No. 99710. (1990, November 21). Brasília, DF: Presidência da República. Retrived from http://www.planalto.gov.br/ccivil_03/ decreto/1990-1994/D99710.htm

Eisenhower, A. S., Baker, B. L., \& Blacher, J. (2007). Early student-teacher relationships of children with and without intellectual disability: Contributions of behavioral, social, and self- 
regulatory competence. Journal of School Psychology, 45(4), 363-383. doi: 10.1016/j. jsp.2006.10.002

Fachinetti, T. A., Nascimento, B. A. B., \& Giroto, C. R. M. (2016). O trabalho pedagógico para alunos público-alvo da educação especial: Investigando a inclusão na educação infantil. Revista IberoAmericana de Estudos em Educação, 11(2), 861-880. doi: 10.21723/riaee.v11.esp2.p861880

Fakolade, O. A., Adeniyi, S. O., \& Tella, A. (2009). Attitude of teachers towards the inclusion of special needs children in general education classroom: The case of teachers in some selected schools in Nigeria. International Electronic Journal of elementary education, 1(3), 155-169. Retrieved from https://eric. ed.gov/?id=EJ1052033

Fantacini, R. A. F., \& Dias, T. R. S. (2015). Professores do atendimento educacional especializado e a organização do ensino para o aluno com deficiência intelectual. Revista Brasileira de Educação Especial, 21(1), 57-74. http://dx.doi. org/10.1590/S1413-65382115000100005

Fernandes, J. D. S. G., Andrade, M. S., \& Ferreira, V. S. (2017). Estudo sobre a relação professor-aluno. Revista de Pós-graduação Multidisciplinar, 1(2), 395-408.

Fernandes, S., Maciel, R. H., \& Carlotto, M. S. (2016). Propriedades psicométricas da escala de percepção de estressores ocupacionais dos professores (EPEOP). Revista Quadrimestral da Associação Brasileira de Psicologia Escolar e Educacional, 19(3), 575-583. doi: 10.1590/2175-3539/2015/0193906

Ferreira, M., Prado, S. A., \& Cadaveico, J. F. (2015). Educação inclusiva: O professor como epicentro do processo de inclusão. Revista Nacional e Internacional de Educación Inclusiva, 8(1), $1-13$.

Field, A. (2009). Discovering statistics using SPSS (3rd ed.). London: Sage.

Folkman, S., \& Lazarus, R. S. (1980). An analysis of coping in a middle-aged community sample. Journal of Health and Social Behavior, 21(3), 219-239. doi: 10.2307/2136617

Forlin, C. (2001). Inclusion: Identifying potential stressors for regular class teachers. Educational Research, 43(3), 235-245. doi: 10.1080/00131880110081017
Greguol, M., Malagodi, B. M., \& Carraro, A. (2018). Inclusão de alunos com deficiência nas aulas de educação física: Atitudes de professores nas escolas regulares. Revista Brasileira de Educação Especial, 24(1), 33-44. doi: 10.1590/ s1413-65382418000100004

Grimes, D. A., \& Shulz, K. F. (2002). An overview of clinical research: The lay of the land. The Lancet, 359, 57-61. doi: 10.1016/S01406736(02)07283-5

Hair, J. J. F., Babin, B. J., Anderson, R. E., \& Tatham, R. L. (2009). Análise multivariada de dados (6th ed.). Porto Alegre, RS: Brookman.

Hwang, Y. S., \& Evans, D. (2011). Attitudes towards inclusion: Gaps between belief and practice. International Journal of Special Education, 26(1), 136-146.

Katz, J., \& Mirenda, P. (2002). Including students with developmental disabilities in general education classrooms: Educational benefits. International Journal of Special Education, 17(2), 14-24.

Law No. 13005. (2014, June 25). Plano Nacional de Educação (PNL) 2014-2024. Brasília, DF: Câmara dos Deputados. Retrieved from http:// www.planalto.gov.br/ccivil_03/_ato20112014/2014/lei/113005.html

Macedo, A. M. B., \& Medina, G. B. K. (2017). O que dizem os estudos brasileiros sobre o relacionamento interpessoal no ambiente escolar: Uma revisão de literatura. Revista Psicologia FAE: Pluralidades em Saúde Mental, 6(1), 93114.

Magalhães, R. C. B., \& Soares, M. T. N. (2016). Currículo escolar e deficiência: Contribuições a partir da pesquisa-ação colaborativo-crítica. Cadernos de Pesquisa, 46(162), 1124-1147.

Malaquias, L. M. A., \& Sekkel, M. C. (2014). Estratégias de enfrentamento dos problemas de escolarização: Revisão de literatura. Temas em Psicologia, 22(2), 271-283. doi: 10.9788/ TP2014.2-01

Marôco, J. (2011). Análise estatística com o SPSS statistics. Pêro Pinheiro, Portugal: Reportnumber.

Mayer, J. D., \& Salovey, P. (1997). What is emotional intelligence? In P. Salovey \& D. J. Sluyter (Eds.), Emotional development and emotional intelligence: Educational implications (pp. 3-34). Nova York: Basic Books. 
McDonald, L., Flint, A., Rubie-Davies, C. M., Peterson, E. R., Watson, P., \& Garrett, L. (2016). Teaching high-expectation strategies to teachers through an intervention process. Professional Development in Education, 42(2), 290-307. doi: 10.1080/19415257.2014.980009

Mello, T., \& Rubio, J. D. A. S. (2013). A importância da afetividade na relação professor/aluno no processo de ensino/aprendizagem na educação infantil. Revista Eletrônica Saberes da Educação, 4(1), 1-11.

Mendonça, A. R. F. (2017). O desenvolvimento socioemocional: A regulação emocional em creche (Master's thesis, Instituto Politécnico de Coimbra, Portugal). Retrieved from https:// comum.rcaap.pt/handle/10400.26/18900

Ministério da Educação, Instituto Nacional de Estudos e Pesquisas Educacionais Anísio Teixeira. (2018, January). Censo Escolar 2017: Notas Estatísticas. Brasília, DF: Ministro da Educação. Retrieved from https://drive.google.com/ file/d/1ul8OptGdTzory5J0m-TvvSzILCrXmWeE/view

Moreira, G. M., \& Sigolo, S. R. R. L. (2009). Roteiros para levantamento de recursos e condições adversas na história pregressa de escolaresprofessores, pais e crianças. In L. N. Weber \& M. A. Dessen, Pesquisando a família: Instrumentos para a coleta e análise de dados (pp. 238-248). Curitiba, PR: Juruá.

Osbourn, H. G. (2000). Coefficient alpha and related internal consistency reliability coefficients. Psychological Methods, 5(3), 343-355. doi: 10.1037/1082-989X.5.3.343

Petrucci, G. W., Borsa, J. C., Barbosa, A. J. G., \& Koller, S. H. (2014). Adaptação cultural e evidências de validade da Escala de Relacionamento Professor-Aluno. Avaliação Psicológica, 13(1), 133-142.

Pianta, R. C. (1992). Student-Teacher Relationship Scale. Unpublished measure, University of Virginia, Charlottesville, VA, USA.

Picado, J. R., \& Rose, T. M. S. (2009). Acompanhamento de pré-escolares agressivos: Adaptação na escola e relação professor-aluno. Psicologia: Ciência e Profissão, 29(1), 132-145.

Pinto, A. M., Lima, M. L., \& Silva, A. L. (2005). Fuentes de estrés, burnout y estrategias de coping en profesores portugueses. Revista de
Psicologia del Trabajo y de las Organizaciones, 21(1-2), 125-143.

Platsidou, M. (2010). Trait emotional intelligence of Greek special education teachers in relation to burnout and job satisfaction. School Psychology International, 31(1), 60-76. doi: 10.1177/0143034309360436

Poker, R. B., Valentim, F. O. D., \& Garla, I. A. (2017). Inclusão escolar e formação inicial de professores: A percepção de alunos egressos de um curso de Pedagogia. Revista Eletrônica de Educação, 11(3), 876-889 doi: 10.14244/198271992016

Portaria $n^{\circ} 948$. (2008, January 07). Política Nacional de Educação Especial na Perspectiva da Educação Inclusiva. Brasília, DF: Ministro da Educação.

Portilho, E. M. L., Batista, G. D. P., Banas, J. C. B., \& Oliveira, S. R. (2017). Estilos de ensino e prática pedagógica. Journal of Learning Styles, 9(18), 135-152.

Rosin-Pinola, A. R., \& Del Prette, Z. A. P. (2014). Inclusão escolar, formação de professores $\mathrm{e}$ a assessoria baseada em habilidades sociais educativas. Revista Brasileira de Educação Especial, 20(3), 341-356. doi: 10.1590/S141365382014000300003

Santos, J. F. (2016). A afetividade e as relações dos professores e alunos com deficiência: Concepções docentes [Monograph]. Natal, RN: Universidade Federal do Rio Grande do Norte. Retrieved from http://monografias.ufrn.br:8080/ jspui/handle/123456789/2556

Santos, R. M., \& Batista, P. C. (2015). Inclusão escolar: $O$ ideal que necessitamos e o real que vivemos. Revista Caribeña de Ciencias Sociales. Retrieved from http://www. derechoycambiosocial.com/revista042/ INCLUSAO_ESCOLAR.pdf

Santos, T. C. C., \& Martins, L. R. (2015). Práticas de professores frente ao aluno com deficiência intelectual em classe regular. Revista Brasileira de Educação Especial, 21(3), 395-408. doi: 10.1590/S1413-65382115000300006

SekkeL, M. C., Zanelatto, R., \& Brandão, S. L. (2010). Ambientes inclusivos na educação infantil: Possibilidades e impedimentos. Psicologia em Estudo,15(1),117-126. 
Silva, L. M. M. A. (2015). A literacia emocional em sala de aula: A importância da empatia na relação pedagógica professor-aluno para o sucesso do ensino-aprendizagem na disciplina de Economia A (Master's thesis, Universidade de Lisboa, Portugal). Retrieved from http:// repositorio.ul.pt/han dle/10451/20648

Skaalvik, E. M., \& Skaalvik, S. (2015). Job Satisfaction, Stress and Coping Strategies in the Teaching Profession - What Do Teachers Say? International Education Studies, 8(3), 181. http://dx.doi.org/10.5539/ies.v8n3p181

Tsai, E., Fung, L., \& Chow, L. (2006). Sources and manifestations of stress in female kindergarten teachers. International Education Journal, 7(3), 364-370

United Nation Educational, Scientific and Cultural Organization. (1994). Declaração de Salamanca e linha de ação sobre necessidades educativas especiais. In Conferência Mundial sobre Necessidades Educacionais Especiais, Spain.

Vargas, R. M. (2015). Senso de autoeficácia dos professores na inclusão de um aluno com autismo na educação infantil [Monograph]. Porto Alegre, RS: Universidade Federal do Rio Grande do Sul. Retrieved from https://www.lume.ufrgs. br/bitstream/handle/10183/141430/000992377. pdf? sequence $=1$
Vaz, S., Wilson, N., Falkmer, M., Sim, A., Scott, M., Cordier, R., \& Falkmer, T. (2015). Factors associated with primary school teachers' attitudes towards the inclusion of students with disabilities. PloS ONE, 10(8), 1-12. doi: 10.1371/journal.pone.0137002

Veiga-Branco, A. V. (2004). Competência emocional. Coimbra, Portugal: Quarteto.

Vilaronga, C. A. R., \& Mendes, E. G. (2014). Ensino colaborativo para o apoio à inclusão escolar: Práticas colaborativas entre os professores. Revista Brasileira de Estudos Pedagógicos, 95(239), 139-151. doi: 10.1590/ S2176-66812 014000100008
Received: 03/04/2018

$1^{a}$ revision: 05/07/2018

$2^{a}$ revision: 06/09/2018

Accepted: 07/09/2018 